the wild is probably low, but we believe that it merits consideration.

Social conditions in Afghanistan have prevented any substantial rabies prevention program. Consequently, prevalence of rabies among wild animals and pets is unknown and could be higher than in other countries. Absence of any documented human deaths from $B$ virus in a country with a developing medical system and a high mortality rate does not confirm absence of risk. $\mathrm{B}$ virus has been shown to be fatal in other areas, particularly in countries with greater medical diagnostic capacity (4).

Engel et al. suggest that recorded monkey bites occurred because affected persons flouted rules prohibiting contact with local animals. Given the unpredictable nature of operations in Afghanistan, it is impossible to determine fault for the animal bites detailed. Furthermore, blaming bite victims may be counterproductive, exacerbating underreporting and discouraging deployed personnel from seeking needed care. We believe that the role of command support and responsibility cannot be overemphasized in preventing deployed personnel from interacting with local animals (5). We thank Engel et al. for providing additional perspective on the risk for monkey bites to personnel deployed in Afghanistan.

\section{Acknowledgment}

This study was conducted exclusive-

ly as part of our service as active duty US Army officers.

\section{Luke E. Mease and Katheryn A. Baker}

Author affiliations: Army Health Clinic, Dugway Proving Ground, Utah, USA (L.E. Mease); and General Leonard Wood Army Community Hospital, Fort Leonard Wood, Missouri, USA (K.A. Baker)
DOI: http://dx.doi.org/10.3201/eid1904.121876

\section{References}

1. Engel GA, Fuentes A, Lee BPY-H, Schillaci MA, Jones-Engel L. Monkey bites among US military members, Afghanistan, 2011. Emerg Infect Dis. 2013;19:69/.

2. Mease LE, Baker KA. Monkey bites among US military members, Afghanistan, 2011. Emerg Infect Dis. 2012;18:1647-9. http://dx.doi.org/10.3201/eid1810.120419

3. Centers for Disease Control and Prevention. Imported human rabies in a U.S. Army soldier-New York, 2011. MMWR Morb Mortal Wkly Rep. 2012;61:302-5.

4. Huff JL, Barry PA. B-virus (Cercopithecine herpesvirus 1) infection in humans and macaques: potential for zoonotic disease. Emerg Infect Dis. 2003;9:246-50. http://dx.doi.org/10.3201/eid0902.020272

5. Chretien JP. Protecting service members in war-non-battle morbidity and command responsibility. N Engl J Med. 2012;366:677-9. http://dx.doi.org/10.1056/ NEJMp1112981

Address for correspondence: Luke E. Mease, Army Health Clinic, 5116 Kister Ave, Dugway UT 84022, USA: email: luke.mease@us.army.mil

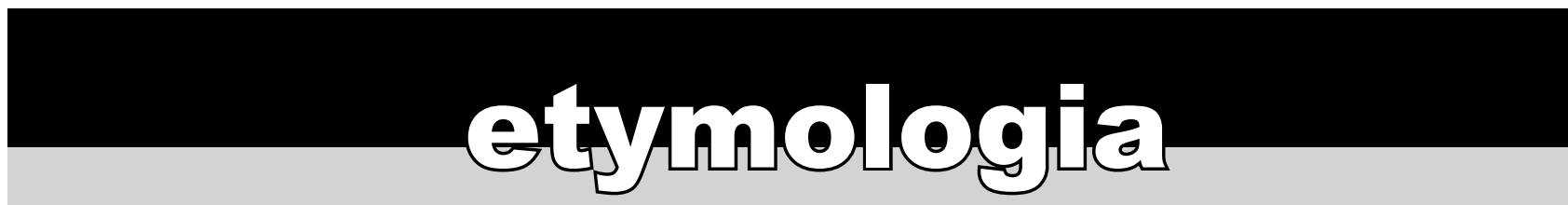

\title{
Syncytium [sin-sish'e-əm]
}

$\mathrm{F}$ rom the Greek syn (together) and kytos (receptacle, vessel), a multinucleate mass of protoplasm produced by the merging of cells. Respiratory syncytial virus was discovered in 1956 by Morris et al., who isolated it from a group of chimpanzees with respiratory symptoms.
Morris originally called the new agent "chimpanzee coryza agent," although when Chanock et al. confirmed that the agent caused respiratory illness in humans, it was renamed because "the striking characteristic of these viruses is the production of syncytial areas in tissue culture."

\section{Sources}

1. Chanock R, Finberg L. Recovery from infants with respiratory illness of a virus related to chimpanzee coryza agent (CCA). II. Epidemiologic aspects of infection in infants and young children. Am J Hyg. 1957;66:291-300.

2. Dorland's Illustrated Medical Dictionary. 32nd ed. Philadelphia: Elsevier Saunders; 2012.

3. Hall CB. Respiratory syncytial virus. In: Mandell GL, Bennett JE, Dolin R, editors. Principles and practices of infectious diseases. 7th ed. Philadelphia: Churchill Livingstone; 2010. p. 2207-21.

Address for correspondence: Ronnie Henry, Centers for Disease Control and Prevention, 1600 Clifton Rd NE, Mailstop E03, Atlanta, GA 30333, USA; email: boq3@cdc.gov

DOI: http://dx.doi.org/10.3201/eid1904.ET1904 